では定着した。日本ではようやくその流れが出 てきたが、3.0の時代で必要となるはずの社会 的な問題を考えるための人材はまだ圧倒的に足 りていない。

文理の分断も、新しい傾向を我が物として取 り入れていくための足枷になっているように みえる。最近日本語での議論を見ていて個人的 に戸惑ったのは、経済学や経営学関係者によ る「イノベーション」と科学技術政策関係者の それとが、あまり重なっていないように感じた ことだ。民間企業や福祉政策など「社会」的領 域のイノベーションと、理工系のイノベーショ ンがどうも別々に語られている印象がある。無 論、私の䛊解もあるかもしれないし、そもそも innovationというのは英語の専門論文において もその多義性、曖昧さが批判されてきた概念で あるようだ。ただ、それでも日本語の議論にお いては、最先端の経済学的議論を知りながら先 端的技術を深く論じようとする論者や、逆に科 学・技術に通じながら英米のイノベーション論 に蓄積されたような社会的な視点を語る論者が 少ないように感じている。

\section{おわりに}

最後に、文系理系という枠組みがこれからど
うなるのかを少し考えて終わりたい。全体と しては、文、理、あるいは人文社会科学、自然 科学という枠組みを人々は意識しない方向に向 かってはいる。実際、大学の学部は学際的にな り、研究においても実際に総合系とか学際的分 野というものが増大している。

学問の細分化は学問統一の欲望、すなわち学 問はひとつでこれからは文系理系もないという 議論を誘発する傾向がある。この数世紀の間に も細分化が起きては、統一が論じられることの 繰り返しだった。今後、学問の分類がどの形に 落ち着くのかはわからない。20世紀末以降の状 況で新しいのは、情報技術の発展により、多様 な分野の成果へのアクセスが圧倒的に容易に なっていることである。己の専門を持ちつつも、 必要に応じて他の分野を教養として学び、自分 に必要な能力を適宜習得できる力が求められる 時代になってきているとは感じる。

とはいえ、まずは日本の場合の当面の課題は、 他国に比べても層が厚いとは言えない人文社会 科学の知に通じた人材をもっと適切に活かして いくこと、それと並行して文理を問わず多分野 を俯瞰できる人材を育成し、きちんと評価して いくことであると思う。

\title{
総合 討論
}

狩野〉専門化や分断の方向から、文理を問わず 多分野を俯政できる人材を育成すること、つま り細かくなっているものを橋渡しできる人が大 事だと思う、というお話と受け止めました。自 分は橋渡しをしていきたい性分なので、是非に、
と思っております。ただ、例えば鎌倉時代の道 元による言葉を伝える『正法眼蔵随聞記』に、「や はり専門であるべきであって、広くを知ろうと してもいけない」ととれる趣旨の内容（「広学 博覧は、かなふべからざる事也。一向に思ひ切 
て留るべし。など）が見られます。専門化を 思わせる方向は日本に 800 年も前からあったの か、と思ったりもし、専門化という趣向のルー ツもまたなかなかに深いかも、と思います。こ うした橋渡しのような考え方や役割が、上手に 根付いたような歴史が、もし日本やその周辺で 存在したら、教えてください。

隠岐〉多分野をつなごうとする人はいたずらに 広く知ろうとしているわけではなくて、ただあ る専門と専門の間の、人々が注意を向けていな いところを知ろうとしているだけなので、知識 の総量自体は一つのことを知る専門と同じでも いいと思うのです。そのため、広く知ろうとし てはいけないという主張と対立するものではな い気がします。現状では、つなぐ役割の人が充 分に活躍出来ているとはいえず、「なんでそこ に興味持つの」「中途半端な人」などの感情を 向けられて、充分に実力が発揮できていないの ではないかと懸念しています。

専門の橋渡しが根付くかどうかについては、 全く同じ話ではないですが、明治期に専門分化 していた西洋の学問体系を受け入れたとき、西 周がむしろ一つの分野に特化して他には口を出 さないという「専門」の概念に驚いていました。 少なくとも彼が親しんでいた考えではなかった ようです。思い起こせば、西洋でもルネサンス 期には専門性という発想はありませんでした。 偏りなく知っている方が望ましかったのです。 たた、近代以降は情報量が爆発的に増えました ので、実践的な次元で専門化が必要になりまし た。今は更に情報が増えて、 discipline 同士の 相互不理解が進んだり、あるいはその分類自体 が不便さをもたらしたりしたので再び広い視野 が要請されているという段階なのでしょう。

有本〉イノベーション政策 $1.0 、 2.0 、 3.0$ といっ
た議論は 60 年代くらいから始まっていると思 うが、隠岐先生は歴史家としてもっと長いレン ジで考えておられる。そこをもう少しお聞きし たい。近代科学技術の価值観とシステムをどう するのか。ギリシア時代からのイノベーション という言葉の変遷を分析されて、フランシス・ ベーコンのところで変わっているのではないか と見ておられる。イノベーションというのは 元々悪い言葉、悪い概念だった。社会を壊すも のだった。ベーコンから社会を良いものにする との意味に変わった（啓蒙主義かもわかりませ んけど)。2018 年秋の INGSA（国際科学助言 者会議）でも議論した Enlightenment 2.0 です。 新しい時代に合わせて啓蒙思想というのを根 本的に点検しないといけないのではないかと。 ヨーロッパが言いだしたんです。日本は明治以 来追随してきたのですが、それをどうするのた ということを踏まえてお聞きしたい。「知識の ための科学」に加えて「社会のための科学」を 提起したブダペスト宣言（1999 年）は、私は 科学の側から近代科学の問い直しを提起したの だけども、政策としては入ったけども、科学の ボトム (現場) のところで十分実践されずに空 回りしながらここまで来た。今、新たにSDGs とか $\mathrm{AI}$ の発展によって深く問い直しを迫られ ている。人文学社会科学の人たちにはそういう 視点から、シリアスに、critical に積極的に発 言してほしい。隠岐先生のご意見を承りたい。

隠岐》啓蒙思想が見直しを必要とする課題とい う視点自体は、思想的な議論においては繰り返 し提唱されてきました。たた、確かに欧州委員 会の Joint Research Center で試みられている

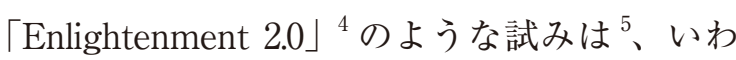
ゆる「科学の政治」に関わるアクターを正面か ら巻き込んでいる点において、かつての議論と 
は異なっているようにみえます。無論、それが 欧州の政策研究サイドから提唱され、日本はひ とまず追随する流れとなっているのは私も残念 に思っています。

JRCの「Enlightenment 2.0」は、ポスト・トゥ ルースの時代とされる今日において、実証的な データを用いて説得しようとしても、価值観が 絡む事柄について人を説得するには限界がある かもしれないという問題に正面から取り組もう としています。いわゆる啓蒙以降の近代化の過 程においては、個々人が理性的に考え、意思決 定できるようにするための教育を施せば、自由 で平等な個人から成る世俗的な社会へと向かっ ていくのだと理解される傾向がありました。し かし現実にはそうはならなかった。たとえば、 全人類の遺伝的な違いは僅かなものであるとの データを突きつけられても納得せず、「奴隷の 存在は聖書が肯定している」「白人は優れてい る」という価值観にこだわる人びとがいつまで も残り続けたりしているわけです。

啓蒙のやり方では、確かにすくいきれなかっ た人間のある性質があって、それを汲み取らず に科学・技術によるイノベーションを進めて世 の中を変化させていくと、とりわけそれが経済 格差を伴う変化である場合、社会が分裂を深め ていくのではないか。個人的にはそういったイ メージを持っています。確かに今ターニングポ イントかなと思います。

イノベーション政策というのは、innovation という語の定義にある通り、変えないといけな い、変化を早めないといけない、という価值観 を不可避に孕んでいます。それが近代を駆動し た意識でもありました。ハートムト・ローザ (Hartmut Rosa) というドイツの哲学者が、近 代化というのは加速化であったと言っていま
$す^{6}{ }^{6}$ しししながら、変化には恐らくいいもの も悪いものもある。変化するということは、変 化に反応しない人と変化に好んでついていく人 が生まれるということです。それでも変化の幅 とその速度が一定度内に留まっている間はよい のですが、21 世紀にはそれが極端になってい るのではないか。たとえば民主主義的な議論と いうのは基本的に時間がかかります。しかしそ うしたあり方を遅いとみなす感性すら助長する レベルの速度で変化が起きるに至ってしまって いる。先端的な技術革新はその顕著な例で、大 抵の場合、もう国民全員の同意を取ることなど 非現実的なので視野に入れず、多くの人が気づ かないほどのスピードで物事が変化していきま す。

しかしそうはいっても加速化には限界がある はずです。これは前述のローザの英語版翻訳者 があげていた例ですが、冷戦時代に、核ミサイ ルの迎撃装置を開発していて、ある段階まで進 んだとき、非常に反応速度がよくなりました。 敵国からミサイルが発射されたのを警報で察知 して人間が迎撃を判断するよりも、もう全部自 動化して機械の反応に任せた方が効率がよいと いうレベルになったのです。しかし、そうなっ た時点でアメリカもソ連もさすがに戸惑いを覚 えて、やはりそうした機械システムの開発に全 力を注ぐよりは、両国の首脳が納得して電話で 話す機会を作る方がよいとの結論に至り、ホッ トラインが創設されたのでした。人間はやはり 自分で判断する時間が欲しいのです。このよう に、加速化の欲望というのは必ずどこかで、人 間性のあり方と衝突し、待てよ、と立ち止まる 時間がどこかに現れる。地球環境の持続性すら 問題となっている現代はまさにその時代なので はないでしょうか。 
黒田》科学と社会、もしくは、技術と社会の関 係性において、どちらがどう回転して、相互 に関係しあってきたかという歴史を考えてみる と、科学的思考が進んで技術が出来てきて社会 を変えていったということもあるし、その社会 を変えたいと思って技術者が新しい技術を開発 して、それを科学的に説明するという順序もあ る。いろいろな形でその三者が回転しているよ うな気がして仕方がない。そのときに肝心なの は、科学というものがもし知識であるとすると、 知識の体系をどうイノベートするかというのが 一番のイノベーションであるはずのものが、経 済学的には、経済成長や社会経済的な豊かさを もとめることがイノベーションであり、それ自 身がイノベーションの目的になってしまったよ うな気がする。今、そうではないという考方方 が少し現れてきているのではないか。なぜかと いうと、そうやって追ってきた成長や豊かさの 追求が、社会に各種の問題を起こしている。所 得の不平等、格差の拡大といった現象も、その 一つの大きな課題であり、それが、人間の豊か さの意味を変えてしまうということになってい るように思われる。そうなると、経済学者がい くら社会を豊かにするにはどうイノベートすれ ばいいかなんてことを考えても根本的な問題は 解決しない。知識の体系そのものをイノベート するような体系を考えていかないと全体の循環 がうまくいかないのではないか、と考えてしま う。最近提案されている啓蒙 2.0 といわれる議 論の発想の根底にそのような問題意識が、あり そうな気がする。

そこで、ひとつお聞きしたいのは、今なぜそ ういう状態になってきたのか。やはり情報科 学などの科学の進歩が社会や技術に与えた影響 とかというのは、今までの科学の性質とは全く
違った性質を持っている気がする。そこのとこ ろを考えようとすると、そこで起こっている問 題はどうしても社会科学と自然科学が一緒に なって考えないと解決できない問題になってい るということが今問われているのではないかな という気がしています。そういうことについて の㧍考えを少しお聞かせいただきたい。

隠岐〉「知の体系をイノベートする」ことが重 要な課題だというのは確かに同意です。前述の 「Enlightenment あるいは啓蒙 2.0」でも、学術 的なアウトプットの社会へのインパクトを考慮 するにあたり、「理性だけではなく感情に着目 する必要がある」という趣旨の議論がなされて いました。実は文学や芸術の分野では、啓蒙思 想の時代の後に 19 世紀にロマン主義という流 れがあったので、この主張自体に新しさは感じ ないのですが、今回は政策研究、それも自然科 学や社会科学を総動員したドキュメントで真剣 に言及されているのがポイントだと思います。 特に20 世紀の歴史を振り返ると、「理性」はし ばしば「経済的合理性」にすり替えられ、政 策を実行するときに絶対的な論点として機能し がちでした。そうした流れに反省の気運が出て きています。たた、そうはいってもこれからど ういう形になるのかというのは明確には見えて はいないです。しばらくは今ある知識の体系を 使って分析するしかないのでしょう。

情報科学が起こした変化の独特さを自然科 学、社会科学两方がタッグを組んで分析しない といけないということについても同意するしか ありません。ただ、既にある程度の蓄積がなさ れてきたということも言及しておきたいと思い ます。まず、皆様ご存じのように、既に情報倫 理に関する様々なプロジェクトが立ち上がって います。それに加えて、私が改めて指摘してお 
きたいのは、1970 年代からの議論の蓄積です。 それは哲学的な領域にも及んでいます。以前、 日本で「ニューアカブーム」といわれた時代に、 ジャン＝フランソワ・リオタールという哲学者 による『ポスト・モダンの条件』という本が一 部の分野で紹介されていました。同書は「大き な物語の終焉」というキャッチフレーズと共に、 当時は流行の「現代思想」として消費された感 があります。しかし今それを読み返すと、彼は 情報化社会について正面から論じようとしてい たことに気づきます。実際、同書はカナダの高 等教育政策のため、「最も発展した工業社会に おける（研究と教育の非公式あるいは公式の制 度の）知の条件を検証する ${ }^{7}$ という行政から の諮問を受けて彼が書いた報告書が元になっ ています。その同報告書においてリオタール は、知識が情報として流通するようになったと きに、効率や市場での価值が非常に重視される ようになること、その帰結として人々の世界観 がどう変わるかということを論じました。一部 には、今日に至る科学研究政策のあり方を予測 するかのような内容もあります。彼の報告書の
影響がどの程度あったのかは不明ですが、いず れにせよ、この種の複数分野を巻き込んだ議論 が蓄積された上で、現在の北米地域における情 報科学の興隆もあると考えた方がよい気がしま す。

注

1 本稿は次の拙著の内容を主に用いている。隠岐さや香『文 系と理系はなぜ分かれたのか』星海社新書、2018年。

2 文部科学省科学技術・学術政策研究所『科学技術指標 2018』、NISTEP Research Material, No. 274, 125 頁。

3 Johan Schot and W. Edward Steinmueller, Framing Innovation Policy for Transformative Change: Innovation Policy 3.0, Science Policy Research Unit (SPRU), University of Sussex, DRAFT, 4 September 2016. 詳細は隠岐、前掲書、 第三章参照。

4 Joint Research Centerは2,000人ほどの研究者を雇用し、 欧州の政策プロセスにおける研究の価值やインパクトを最 大化するための調査を行っている。Enlightenment 2.0では、 複数分野の専門家を集めて、政治的言説や政治的決定を駆 動する要素の分析を行っている。なお、カナダの哲学者ジョ ゼフ・ヒースの同名の著書とは直接の関わりはない。

5 https://ec.europa.eu/jrc/en/news/jrc-launches-call-expertsenlightenment-20

6 Hartmut Rosa, Social Acceleration: A New Theory of Modernity, translated by Jonathan Trejo-Mathys, Columbia University Press, 2013 [ ドイツ語版原著は2005年初版］。

7 Jean-François Lyotard, Rapport sur les problèmes du savoir dans les sociétés industrielles les plus développées, fait au Président du Conseil des Universités auprès du Gouvernement du Québec, Paris, April 1979, p. 1.

科学と社会研究会（「科学者の集まり」）は、以下の企業をはじめとする各企業及び篤志家の 御協力（寄付金、賛助会費）により運営されています。

AGC株式会社 大成建設株式会社 株式会社三菱ヶミカルホールディングス 三菱電機株式会 社 大久保勇作・閲子様 